\title{
"You'll Get Used to It": Alterity in Jean Rhys' Voyage in the Dark
}

\author{
HIBA METEAB FAJA \\ Centre for Research in Language and Linguistics, \\ Faculty of Social Sciences and Humanities, \\ Universiti Kebangsaan Malaysia \\ RUZY SULIZA HASHIM \\ Centre for Research in Language and Linguistics, \\ Faculty of Social Sciences and Humanities, \\ Universiti Kebangsaan Malaysia \\ ruzy@ukm.edu.my \\ AMRAH ABDUL MAJID \\ Centre for Research in Language and Linguistics, \\ Faculty of Social Sciences and Humanities, \\ Universiti Kebangsaan Malaysia
}

\begin{abstract}
Due to the complex intersecting parameters of identity, race, class, and history of Jean Rhys' writing life, her works allow for interpretation from various disciplines. Rhys' writings reveal the realities of people caught in the complexity of such a web. Her 1934 novel Voyage in the Dark provides insights into the life of Anna Morgan, the heroine of this novel who moves from her home in Dominica to England to face the entire psychological and social struggle by her journey that ends her up with destruction caused by the challenges that seem to conspire to her tragic fate. In understanding the life of Anna Morgan, the woman who has been told that she will "get used" to her circumstances, the concept of alterity is a useful reading approach in unveiling the push and pull factors that drive her to her downfall. As a concept, alterity is explained in this paper through making overt the structure of the novel that exposes various factors that markedly contain facets of alterity such as alienation, assimilation, and separation. By appropriating this reading lens, we hope to show how multiple factors machinate to show the systematic ways in which Anna Morgan's fate is sealed when the heroine herself and others around her cannot accept otherness and fusion.
\end{abstract}

Keywords: Jean Rhys; alterity; gender; class; ethnicity

\section{INTRODUCTION}

The phrase, "You'll get used to it" is a refrain that plays in the mind of Anna Morgan, the protagonist in Voyage in the Dark, as she is shown to be sucked into a life that is characterised by dejection and hopelessness. This third novel of Jean Rhys exemplifies the intersections of gender, class, and ethnicity as Anna attempts to fit into a society that preys on her disadvantaged situation. Rhys was a woman of complex combinations: Caribbean, English, white Creole. Her novels exhibit some of these oppositions and paradoxes. Essentially, her writing style and depiction of race, ethnicity, class, sex and nationality emphasised her contribution and place in Caribbean writing and culture. Her writings are both conventional and avant-garde, both colonial and anti-colonial. These contrasts of attitudes demonstrate her refusal to be completely rational and her inclination for ambiguity, as well as her uncertainty of wanting to belong and to be independent from either one of the cultures (Rosenberg, 2007).

Insight into the life of Rhys is necessary to see the close resemblance of her lived realities with the life of her protagonist in the novel. Rhys was born in Roseau, the capital of Dominica, an island in the British West Indies. A mixed family of a Welsh father and a Dominican Creole of Scottish descendant mother, Rhys was shown to be caught between the two cultures that psychologically destabilised her sense of being. Anne Simpson (2005) views 
Rhys' writings as mirroring her upbringing. She was tested repeatedly in England where she pursued her studies; Rhys herself reflected that she "was always outside, shivering" (Vreeland, 1979, 221). Her confession is similar to V.S Naipaul's declaration of feeling alienated, as M. Mehni, Noritah Omar and Ida Baizura (2015: p.95) highlighted that being "separated [from] his racial and cultural roots and driven into exile from his land of birth" influenced the focus of his writing life. Analogously, Rhys' admission of being an outsider suggests that she had always felt excluded - a feeling that characterised much of her childhood which became more ominous in her adulthood, and this becomes much of preoccupation in her writings.

This brief incursion into Rhys' life renders Voyage in the Dark as almost autobiographical. Just like Rhys, Anna is caught in a vortex of rejection and unhappiness brought about by her feelings of otherness. Her ethnicity, gender, and class confuse herself as much as they confound those around her. Hence, this article is an attempt to understand these parameters that define Anna as exemplifying aspects of alterity.

\section{LITERATURE REVIEW}

Due to resemblance of episodes in Rhys' own life, most studies show connections between fact and fiction. Any reading of Rhys is not complete without a focused study on her biographer (Angier, 1990). Angier followed Rhys' entire life and studied the psychological changes through her stories, novels, unfinished biography of Smile Please, and letters. By presenting Rhys in the perspective of the times of her life, Angier claims that Rhys, throughout her life, was completely dependent on men to support her. Her major concern was to find acceptance and love within the environment she lived in so that she could find her identity and psychological settlement (Angier, 1990). In terms of her writing, Rhys is partly progressive as "her heroines are modern: homeless and alone, in a shifting, uncertain dangerous world" ( $p$. 15). Rhys' voice as a writer "is utterly modern: moody and disillusioned, honest and mocking" (p. 15). But at the same time, she was traditional as "she explored her own age, its mood, and changes, almost by accident. Rhys expresses her psychological urges through her earnest involvements and moods as well as "experiences of love and rejection, hate and revenge, fatality and fear" (p. 16). Elaine Savory (2009) also drew on Rhys' life, emphasizing on Rhys' race, religious education and class which became fodder was her novels. As Savory (p. 13) aptly captures:

In the colonial Caribbean, she belonged to the elite, but in England she was working as a chorus girl and an outsider as a Creole. She invented herself several times and longed to break out of the categories to which others consigned her. In her fiction, she explored these tensions and contradictions.

Savory highlights the close proximity of Rhys' life with Anna's situation in England. In a much later study, Ledent (2018) arrives at the same conclusion by saying that Rhys uses the situation of her life to escape her psychological suffering. Hence, the connectedness of Rhys' own experiences inform much of her writings, making them insightful in reading her works.

Other reading lenses have been equally important in interpreting Rhys' novels. Psychoanalytical studies are popular, especially in making overt various states of minds and relationships of the novelist's characters. In her extensive study of Rhys' works, Simpson (2005, p. 20) appropriates psychoanalytical theories drawn from Klein, Riviere, Winnicott and others to examine "the fraught conditions of psychic experience, the dense layers of feelings within the individual, ... expressed in both the words she chooses with such care and the silences that resonate so fully in one Rhys narrative and then another." In a later study, Duffy (2015) focuses on the aspect of Oedipal complex that consumes Anna in Voyage in the Dark. 
According to Freud, any relationship between a young woman with an older man is due to her desire to re-live childish affection which is represented as a psychological shield to protect her present self from strange men. This is the basis that underpins the relationship between Anna and Walter. Mother-daughter relationship is also the focus of a number of scholars; for example, Victoria Burrows (2004) suggests that Anna's longing "to be black. I have always wanted to be black" (Voyage in the Dark, p. 27) as related to her yearning to be loved by her mother who loves black children. The psychological lens renders many interesting facets of her fiction, allowing relationships and emotions to be dissected and understood.

The feminist postcolonial perspective in reading Rhys' novels is by far the most prevalent method of inquiry. Her writings represent the marginal woman, rejected and exiled from her culture and sexuality. Nebeker (1981, p. ix) argues her heroines "are not able to escape stereotypical descriptions as regular victims in patriarchal male-dominated world who are in continual search of identity, perpetually seeking to establish a voice. In some way or another, they are often seen as "women estranged probably forever from their archetypal selves". The fragmented perception of the Rhysian woman and her silenced voice reflect the modern experience of alterity, patriarchy, and exile. Like other modernist writers such as Virginia Wolf, James Joyce, and Dorothy Richardson in their perceptions of characters' mindfulness and distinctiveness, Rhys was motivated in explaining the inner selves her characters (Emery 1982). The Rhysian woman is always seen as a passive victim in a male-controlled society in which "the victimization and self-victimization of a woman drifting along the ages of artsybourgeois society" (Moore, 1987, p. 93). Rhys says (1978, p. 70):

I realize that I am being gently pushed into my predestined role, the role of victim. I have never had any good times, never laughed, never got my own back, never dared, never worn pretty clothes, never been happy, never known wild hopes, or wilder despairs. I've forgotten all about it. Wailing, I have gone from tyrant to tyrant; each let down worse than the last.

The Rhysian woman in every novel, beginning from Voyage in the Dark, Quartet, After Leaving Mr. Mackenzie, Good Morning Midnight, and Wide Sargasso Sea show her female protagonists as "besieged by poverty, exile, loneliness, and abasement (E. L. Johnson, 2015, p. 209). The postcolonial critic is often reminded of the fact that Rhys' characters are often removed from the native origin of the Caribbean to feel like outsiders in the domestic traditional world, and trespassers on masculine limits. Helen Carr (2012, p. 11) notes that the feminist scholars show ambivalence about accepting Rhys as a feminist writer, saying that she was "feminine rather than feminist." Her characters "connived too much in their own unhappiness" (p. 11) but they failed to factor in economic, class, colonial and sexual oppressors that abuse the disadvantaged. As H.A. Murdoch (2015, p. 146) argues, "the shifting and structurally unstable inscription of the creole figure echoes ... critical ambiguities of political structure and social position that shaped the colonial encounter in the region." In relation to this, Voyage in the Dark is often cast in a similar tone, as Anna Morgan is read as a woman in search for her lost identity. As a white Creole who is forced to move from the colonial Caribbean world into the imperial world of London, the latter always seems dark and unwelcoming. In another article, Hargreaves (2018) illuminates that Anna's situation brings about a kind of self-crisis in finding her true identity and sense of belonging through the sequence of events in her life.

Based on this brief review, Rhys' novels lend themselves to several interpretations from different critical perspectives such as formalism, feminism, and postcolonialism. Her unique life history that combined English and Caribbean landscapes produced literary works which illuminate women and men caught by the circumstances of their lives due to their marked personal, social and economic differences. After reading and analysing her works, the reader is confronted with multifaceted different ways of reading her, especially in the context of a changing and complicated world. 
In this article, we continue to pursue with the postcolonial feminist lens by extending into issues of alterity. Othered by a number of circumstances - gender, class, ethnicity - Rhys' heroines become the emblematic "other". They are often told of their inferiority that they cannot unsee other alternatives for happier lives. Her works provide admonition for people who are passive because they are manipulated and mistreated by men, and in the long run, their eroded self-esteem leads to enslavement and ruin.

\section{CONCEPTUAL FRAMEWORK}

The term "alterity" is derived from the Latin word alteritas meaning "the state of being other or different; diversity, otherness". Its derivatives in English are "alternate", "alternative", "alternation", and "alter ego". The term alterité is more common in French, and has the antonym of identity (Pinar 2015). Alterity reflects the experience of newness and appears in a surprising way; it may seem like something new, something unfamiliar to the general standards or something that does not follow the general known laws (Skorin-Kapov, 2015). The term "alterity" has been used interchangeably with "otherness" and "difference" in the context of postcolonial theory (Bertelsen \& Bendixsen 2017). However, otherness is deemed to be the outcome of the in-group domination i.e. the "us" or "the self" over the out-group i.e. "them" or the "other" via the establishment of the differences in identity existence, real or imagined, which makes way for the manifestation of discrimination. "Otherness" is created based on the principles that categorize people into two hierarchical groups i.e. "them" versus "us". The outgroup (them) is the opposite of the in-group (us); they exist as adversaries, and whichever group that happens to dominate depending on mainstream politics has the privilege to dictate values and norms. Edward Said, Gayatri Chakravorty Spivak, and Simone de Beauvoir's discussions on difference can aid in fleshing out our understanding on alterity.

We draw on Said's $(1993,2001)$ concept of Otherness, based on his emphasis on the weaknesses of the colonial other against the power of imperial authority. His concept is nearer to Rhys' own colonial encounters in her novels. Said combines the idea of the other with abuse and this abuse is established by the colonial domination of the West through the rationalization of the inferior status of the other in the East. For Said, there are psychological and political pressures in colonialism that produces an uncertain identification concerning the traditional contrast between the self and the other of the discourses of identity. This gives way to a colonial discourse that is ripe with stereotypical ways of representation, such as the association of skin colour with specific behaviors as a justification for discrimination. Consequently, the objective manner of colonialism is to understand the colonized as a population of corrupt forms depending on the basis of racialism. As Qiao Meng and Noritah Omar (2012: p.564) argued, "the treacherous of such racism lied in that it proved to the West and the East at the same time that the colonised were intrinsically inferior, not just outside history and civilisation, but genetically pre-determined to inferiority", and this strategy is employed to legitimize invasion and to institute systems of organizations. Consequently, the colonized people appear in a perpetual state of savagery, and cannibalism, as they are uneducated barbarians, legitimizing the White Man's burden as necessary in saving the natives from perpetual darkness (Nynas 2017). In their study of the emergence of Palestine in the postcolonial Arabic novel, Yahya Hassan Alwadhaf and Noritah Omar also point out that Said (1993) stresses on the agenda of imperial powers as a cultural form that helps in enhancing the colonizer's ideologies, references, attitudes and experiences. Quoting from Said, they say that stories "are at the heart of what explorers and novelists say about strange regions of the world; they also become the method colonized people use to assert their own identities and the existence of their own history" (2011, p. 112). Rhys' story exemplifies the truth of this assertion. 
While Said looks at the concept of otherness from a mainly political sphere, Spivak's work is instrumental in giving voice to the subaltern, which appeared in her article "Can the Subaltern Speak?" Adopting the term "subaltern" from Gramsci, Spivak uses the term to describe the oppressed people or those who have no right to speak up their minds, those who are others, women, and slaves (Spivak 1988, Spivak 2012). She concludes that "the subaltern cannot speak" (308) as they are forced to think that they belong to inferior class and they do not have the right to contribute to their society. She argues that this concept is an apt description of the third world women, mentally-challenged individuals, and those who do not subscribe to a common, acceptable standard. She says:

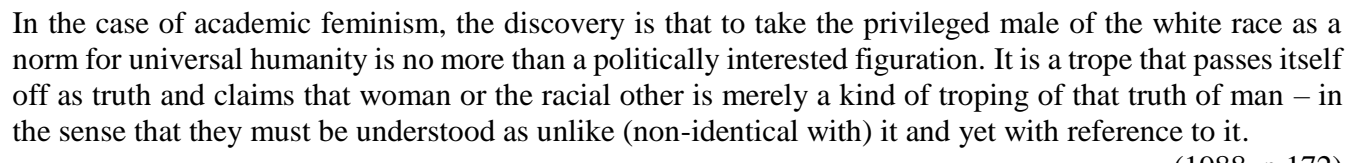

(1988, p.172)

"Can the subaltern speak?" is a rhetorical review and her purpose is to clarify the obstacles of the subalterns. Despite the fact that a woman may please the needs of her man, she is unable to obtain a voice to express disagreement and unhappiness. This argument dovetails the subaltern standards of Western and embodied acknowledge of subjectivity. It simply means that the other interpellates the self-image of colonizer, and she becomes muted because of the interpellation.

It is necessary to return to de Beauvoir who was recognized for her 1949 essay "The Second Sex", provides a comprehensive analysis of women's repression and an initial tract of modern feminism. The use of second sex itself is an example of othering because De Beauvoir (1988) believes that the woman is seen by the society from the perspective of sex. Men and women should complement each other. They share the obligations in supporting the family; however, one sex is privileged over the other. De Beauvoir contends othering is a major classification of human idea. Manliness is viewed as socially developed as the all-inclusive standard by which social thoughts regarding humankind are characterized, examined, and administered. She is the accidental, the dispensable instead of the fundamental: "He is the Subject, he is the Absolute - she is the Other" (1949, p.18). Women are a key part in the process of production and still they are called as" the second sex or the weaker sex":

\footnotetext{
Thus humanity defines woman not in herself but as relative to the man: she is not regarded as an autonomous being... The body of man makes sense in itself quite apart from that of woman, whereas the latter seems waiting in significance by itself ... Man can think of himself without woman. She cannot think of herself without man. And she is simply what man decrees: thus she is called "the sex", by which is meant that she appears essentially to the male as a sexual being. For him she is sex - absolute sex, no less. She is defined and differentiated with reference to man and not he with reference to her; she is the incidental, the inessential as opposed to the essential. He is the Subject, he is the Absolute - she is the Other.
}

De Beauvoir criticizes the idea that men cannot live in the society without considering women as secondary to them. She highlights the rejection of women by asserting that, "Society has always been male; political power has always been in the hands of men... For the male it is always another male who is the fellow being, the other who is also the same, with whom reciprocal relations are established" (p.70). Subsequently, de Beauvoir celebrates the group of women that attempts to reveal society's disrespect and rejection of women as "a separate group set up on its own account over against the male grouping" (p.71). The rejection of a noticeable set of humanity is not specific only to women; it can be found traditionally in relationships with large power gaps and authorial differences. Simply put, women are seen as possessions (Anderson 2019). As Pedram Lalbakhsh (2014, p. 17) argues, men use monstrosity to exert 
power and oppress the other class because they see themselves having power over the women. This is an important concept because Rhys portrays her female character as inferior as they fall deeper into relationships of dependency.

The reason behind the choice of those three scholars is because they complete each other in explaining the concept of alterity; Said covers the political side while Spivak and De Beauvoir are concerned with the social and the psychological results of alterity upon women. Their connected ideas are mingled with one another in making overt the meaning of alterity from different angles. Additionally, the purpose of putting these concepts together is to conclude that alterity, most importantly, refers to anyone or anything that is different from the standard norm. It is not necessary which one is superior to another but the most important thing is that the term "other" is anything that is imagined as being antagonistic to mainstream values, in this case, colonial and English ideals. We outline these scholars because their details on alterity are reflected in one way or another in Voyage in the Dark.

\section{ANALYSIS}

It is necessary to scrutinize the structure of Voyage in the Dark because it lends itself to reading it from the lens of alterity. Its quartet composition emphasizes the degree of otherness that seems to overwhelm the heroine into confusion and despair. Part One provides the background information of Anna Morgan. Orphaned, abandoned by her stepmother, failing in her job as a chorus girl, late teenager Anna begins a relationship with a rich stockbroker, Walter Jeffries, who is twenty years her senior. She falls in love with him but it is not mutual. Jeffries breaks up with Anna through his cousin, Victor, who promises financial assistance as long as she keeps her distance.

In Part One of Anna's story, Rhys establishes various aspects of the protagonist's alterity. She comes from the West Indian. She has no close relatives. Her work is unfulfilling. Anna is also financially insecure. From the very beginning, she finds everything unfamiliar and unfriendly, "the colours were different, the smells different" (p. 7). Anna does not like England; she "couldn't get used to the cold" (p. 7). Hence, she retrieves old recollections of bright colours and smells of the streets, frangipani, cloves, cinnamon. This memory, so acute and powerful, highlights the estrangement of Anna with her current situation, as the protagonist says of herself "in my heart I was always sad, with the same hurt that the cold gave me in my chest" (p. 15). Thus, she feels psychologically lost and in exile which typifies her feelings as the other, as rejection is common from every place she goes to; "oh I'm not going to like this place I'm not going to like this place. I'm not going to like this place- you'll used to like it Hester kept saying" (p.12). Her cultural identity of a mixture between Dominican and English, makes it impossible to find a home or a place that she can grasp her true ethnicity and her true race; instead she keeps questioning her own nature and her own history. She attempts to return to the past and search for anything that can reconcile her damaged soul "sometimes it was as if I were back there and England were a dream. At other times England was the real thing and out there was the dream, but I could never fit them together" (p.8). In Reflections on Exile, Said (2002, p. 36) discusses lost identity and exile:

\footnotetext{
Most people are principally aware of one culture, one setting, one home; exiles are aware of at least two, and this plurality of vision gives rise to [...] an awareness that $[\ldots]$ is contrapuntal. For an exile, habits of life, expression or activity in the new environment inevitably occur against the memory of these things in another environment. Thus both the new and the old environments are vivid, actual, occurring together contrapuntally.
} 
The experience of exile and alienation that Anna faces in the novel seems of another kind; it is a kind of "contrapuntal" awareness in which Said has described the exact state between the new and old origins which are found in a productive way. Anna's story reflects her old memories of the past as a Caribbean girl and the new modern memories in metropolitan society of London which creates a murky image of a pseudo-English girl. Through showing the past as having more life than the present, Rhys succeeds in making her novel a phase for conflict of control between the past culture and the present one. The bitterness and pressure contribute to Anna's disorientation as she is continually torn and misplaced between two domains that are always a mismatch with each other. For Anna, Said's "contrapuntal" awareness comes from an admixture of old and new culture. Anna can be presented being in a limbo which is a difficult and frictional; it is a harsh coexistence between the past and present, exile and home, new and old. She ruminates that "looking out at the street was like looking at stagnant water...I don't like London. It's an awful place; it looks horrible sometimes. I wish I'd never come over here at all" (p.25). This repeated emotion of being different and dejected shows that Anna is not able to accept the duality of her being. She is monocentric - having a single purpose of wanting to fit in. Because of this monocentricity, her main purpose is always trying to fit into the English life, but her old life keeps intruding into her English landscape.

In the second part of the novel, Anna tries to mollify the pain of her break-up. She reaches out to Ethel Matthews, an older woman but in turn, this pseudo maternal woman pushes her into human trade. Anna is shown to be entrenched further into disaffection. She imagines the people round her as creatures; her landlady has "bulging eyes, dark blobs in a long, pink face, like a prawn" (p. 103), Ethel Matthews looks like an ant with a "long face and a long body and short legs" ( $p$ 106). The fact that Anna sees them as insects rather than people emphasizes her disconnection to human faces. However, even in that state of misery, she has a perspicacious instinct of comprehending Ethel's shrewdness "she had her own cunning, which would always save her, which was sufficient to her. Feelers grow when feelers are needed and claws when claws are needed and cunning when cunning is needed" (p. 107). However, despite that internal warning, Anna, desperate for friendship, is drawn into another dependent relationship with the older woman. Here, Rhys reinforces the impact of gender and ethnic alterity. Without a secure income and firm identity, Anna continues further headlong into darkness.

In Part Three, Anna attempts making an earning as a manicurist. She has another lover who soon leaves her, and then she begins to entertain other men. She becomes pregnant but is unsure of the father of her child. Vincent provides her with some financial assistance so that she can abort the pregnancy. Anna's consequent behavior is driven by her financial woes. Termination of her pregnancy highlights the female predicament of having a child out of wedlock without financial support. Anna's problem enhances the economic alterity - sex, love, material comfort, friendship are all driven by money. As Anna's friend, Maudie says, "Isn't it awful losing a chance like that because you haven't got a little money? ... when you're shabby you can't do anything, you don't believe in yourself" (p.160). Maudie states clearly that material physicality becomes the first marker of status. In Part Two, Anna's preoccupation with clothes is already established; here, it gains further traction to show her desire to be on the same foothold as the others who are financially stable.

Part Four describes Anna in agony as she recovers from her botched abortion. At the end of the novel, feeling completely lifeless and miserable and looking to the door in despair, Anna surmises that "I thought I'm going to fall nothing can save me now but still I clung desperately with my knees feeling very sick" (p.158). Moving in and out of consciousness, Anna returns to the happy times of her childhood where she was giddy with laughter and happiness compared to her present time where she is giddy with soreness and loss. Part Four is a very short section that provides foreshadowing of Anna's future life as she reminisces "about 
starting all over again" ... starting all over again, all over again" (p. 188), the doctor's sarcasm and Anna's ambiguous future are put in sharp contrast. The doctor is in a position of power, saying that "she'll be all right ... ready to start all over again in no time, I've no doubt" (p. 187), reducing Anna's hurt and loss as something trivial. However, Rhys is also ambivalent at the close of the novel; Anna sees a "ray of light" as though the future ahead promises something brighter although the novel's title Voyage in the Dark presents dark portending.

The structure of the novel illustrates the degree by which Anna plunges further into her abyss of pain and loss. Part One has the longest narrative and part Four has the shortest. In contrasting the beginning and the ending of Anna's story, Rhys shows us the culmination of gender oppression, economic poverty, and ethnic confusion. This is further enhanced by her childhood upbringing which has her moments of agony, but when they are contrasted to grey and cold England, Anna's memory of childhood seems more convivial.

Rhys depicts a young woman who is trapped in a country that is alien without much resources except for her youth and beauty. Anna's England is aloof, somber, and commercedriven where class matters. Anna is not immature and her insights of people are often correct but the circumstances of gender and economics combine to prey on her needs of being financially and emotionally secure, to be loved, and to feel at home. She is friendless, men abuse her, and even the women seem to collude in making her life a misery. This isolation is partly attributed to her constant feeling of being unable to see England as home. Assimilation is unviable and impractical when only animosity governs both "us" and "them."

The surroundings that Anna finds herself in also contributes to her unhappiness. She is demanded to be someone other than her real self. She loves the chaos of different smells and colours, but in England, everything seems monotonous - drab colours of grey, the towns "looked exactly alike ... rows of little houses with chimneys like funnels of dummy steamers and smoke the same colour as the sky" (p. 8). The search for a room in a home, argues K. Lee (2016) illustrates her constant search for warmth and security. But these places are not welcoming. This disorientation is associated with an encounter with otherness. Having to choose one over the other betrays the loyalty Anna feels towards to land of birth. How could she reject a place that she remembers with fondness? The colonial mentality requires Anna to appreciate the English scheme of things but the juxtaposition of Caribbean mindset and English worldview is too jarring for Anna to embrace full-heartedly. She fails to eliminate the unease and perplexity that her new English environment demands of her, and those around her landladies, friends, lovers fail to come to terms with her difference. Just as she is perplexed by the monotony "everything was always so exactly alike" and dreads "the cold" (p. 179), they are also confounded by her. To them, she is "the Hottentot", to many of her lovers, she is "cold as ice" (p. 13). She remains fragmented; her outer self seeks to accept Englishness, but the inner self retreats further into childlike security of her Caribbean origin.

\section{CONCLUSION}

In Voyage in the Dark, Rhys shows that Anna Morgan is perceptive of the rules of the game in life but she could not "get used to it". Anna buries her longing for establishing identity and her need of love under a façade of feminine behaviors, even if this means producing compromises and physical sacrifices. Unfortunately, Anna's value as a human is measured by class, wealth, and ethnicity. When otherness is thought in binary terms and as absolute, all-or-nothing terms, it encourages us to think of privileging one yardstick over the other.

Rhys highlights the problems that arise when the marginal woman has to live in two societies which are not only different but they are antagonistic in nature as in "us" versus "them". Throughout the novel, the novelist provides many examples of discordant values and 
norms. Anna's exclusion is due to the dominant colonial mindset which shows its biasness because of her difference. By relegating her to the margin, and expecting her to assimilate values which are foreign to her inner psyche, both parties fail to embrace the richness and vibrancy that each culture possesses. Rhys brings to light the tragic consequence when response to otherness is absolute. She raises the value of maintaining respect of otherness - be it gender, class, or ethnicity. The story of Anna Morgan teaches us about bridging distance and understanding, to think of otherness or alterity in non-absolute terms. Rhys emphasizes the obstacles and warnings of closed-mindedness and unwillingness to see beyond the differences of others. Through an understanding of alterity, Rhys, through her protagonist, provides a glimmer of light so that we can start "all over again" (p. 188).

\section{REFERENCES}

Alwadhaf, Y. H. \& Noritah Omar. (2011). Narrating the Nation and its Other: The Emergence of Palestine in the Postcolonial Arabic Novel. 3L: Language, Linguistics, Literature. Vol. 17, 109-119.

Anderson, E. (2019). From Existential Alterity to Ethical Reciprocity: Beauvoir's Alternative To Levinas. Continental Philosophy Review: 1-19.

Angier, C. (1990). Jean Rhys: Life and Work. London: Penguin.

Bertelsen, B. E. \& S. Bendixsen. (2017). Critical Anthropological Engagements in Human Alterity and Difference. Connecticut: Springer.

Burrows, V. (2004). Whiteness and Trauma: The Mother-Daughter Knot in the Fiction of Jean Rhys, Jamaica Kincaid and Toni Morrison. Hampshire: Palgrave Macmillan.

Carr, H. (2012). Jean Rhys. Oxford: University of Oxford.

de Beauvoir, Simone. (1988). The Second Sex [1949], translated and edited by HM Parshley. London: Pan Books.

Duffy, E. (2015). "Nobody Else Knows Me, but the Street Knows Me" - Jean Rhys's Urban Flaneuses: Mapping Good Morning, Midnight. English Independent Study Projects. https:// digitalcommons.ursinus.edu/english_ind/2. Accessed 1 June 2020.

Emery, M. L. (1982). The Politics of Form: Jean Rhys's Social Vision in Voyage in the Dark and Wide Sargasso Sea. Twentieth Century Literature. Vol. 28(4), 418-430.

Hargreaves, T. (2018). "British Women's Fiction of the 1960s." The 1960s: A Decade of Modern British Fiction.

Johnson, E.L. (2015). "Uphostered Ghosts": Jean Rhys's Posthuman Imaginary. In E.L Johnson \& P. Moran (Eds.), Jean Rhys: Twenty-First Century Approaches (pp. 209-227). Edinburgh: Edinburgh University Press.

Lakbash, P. (2014). Subverting Masculine Ideology and Monstrous Power Exertion in Doris Lessinges The Cleft. 3L: Language, Linguistics, Literature. Vol. 20(3), 17-26.

Ledent, B. (2018). Exotic Madness in Caribbean Literature: From Marginalization to Empowerment and Indigenization. In M. Bharat \& M. Grover (Eds.), Representing the Exotic and the Familiar: Politics and Perception in Literature (pp. 309-322). Amsterdam: John Benjamins Publishing Company.

Lee, K. (2016). Out of "Place": Rooms, Dirt, and Narrative of Space in Jean Rhys's Voyage in the Dark." The Explicator. Vol. 74(3), 143-146.

Mehni, M., Noritah Omar, \& Ida Baizura Bahar. (2015). Trauma of Displacement in V.S. Naipaul's The Mimic Men. Asian Social Science. . Vol.11(24), 95-104.

Murdoch, H. A. (2015) The Discourses of Jean Rhys: Resistance, Ambivalence and Creole Indeterminacy. In E.L Johnson \& P. Moran (Eds.), Jean Rhys: Twenty-First Century Approaches. (pp. 146-170). Edinburgh: Edinburgh University Press.

Nebeker, H. (1981). Jean Rhys, Woman In Passage: A Critical Study of the Novels of Jean Rhys. Montreal: Eden Press Women's Publications.

Nynas, P. (2017). Transforming Versus Repressing the Self and the Other in Virtual Language Learning and Teaching. In Transforming Otherness. London: Routledge.

Qiao Meng \& Noritah Omar. 2012. Resistance Against and Collusion with Colonialism: Eileen Chang's Writing and Translation of "Steamed Osmanthus Flower Ah Xiao's Unhappy Autumn." Pertanika. Vol. 20(2), 563576.

Rhys, J. (1968). Voyage in the Dark. London: WW Norton \& Company.

Rhys, J. (1978). "Making Bricks Without Straw." Harpers. Vol. 257(1538), 70-71.

Rhys, J. (2016). Smile Please. London: Penguin.

Rosenberg, L. (2007). Nationalism and the Formation of Caribbean Literature. New York: Palgrave.

Said Edward, W. (1993). Culture and Imperialism. New York: Vintage.

Said, E. W. (2001). Reflections On Exile and Other Literary And Cultural Essays. New York: Granta Books. 
Savory, E. (2004). Cambridge Studies in African and Caribbean Literature: Jean Rhys. New York: Cambridge University Press.

Simpson, A. B. (2005). Territories of the Psyche: The Fiction of Jean Rhys. New York: Palgrave.

Skorin-Kapov, J. (2015). The Aesthetics of Desire and Surprise: Phenomenology and Speculation. London: Lexington Books.

Spivak, G. C. (1988). "Can the Subaltern Speak? In C. Nelson \& L. Grossberg (Eds.), Marxism and Interpretation of Culture." Illinois: Urbana Univ. of Illinois Press.

Spivak, G. C. (2012). In Other Worlds: Essays in Cultural Politics. London: Routledge.

Staszak, Jean-Francois. (2009). Other/otherness. In International Encyclopedia of Human Geography. London: Elsevier. pp. 1-7.

Vreeland, Elizabeth. (1979). "Jean Rhys: The Art of Fiction [Inter- view] LXIV.” Paris Review. Vol. 21(76), 21837. 